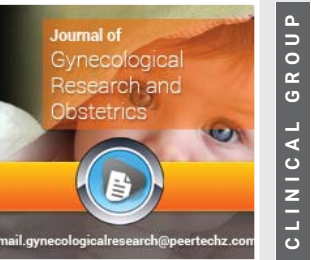

\title{
Conservative management of gestational gigantomastia: A
}

\section{case report}

\section{Kamal El Moussaoui ${ }^{1 *}$, Anas Chenguiti Ansari ${ }^{2}$, Aziz Baidada ${ }^{1}$ and Aicha Kharbach ${ }^{1}$}

'Department of Gynecology and Obstetrics, Maternity Souissi, University Hospital Center Ibn Sina,

University Mohammed V, Rabat, Morocco

2Department of Gynecology and Obstetrics and High-risk Pregnancies, Maternity Souissi, University

Hospital Center Ibn Sina, University Mohammed V, Rabat, Morocco

Check for updates

Received: 28 April, 2021

Accepted: 08 May, 2021

Published: 10 May, 2021

*Corresponding author: Dr. Kamal El Moussaoui, Department of Gynecology and Obstetrics, Maternity Souissi, University Hospital Center Ibn Sina, University Mohammed V, Rabat, Morocco,

E-mail: dr.elmoussaouikamal.gyn.obst@gmail.com

Keywords: Breast diseases; Gestational; Gigantomastia; Macromastia; Pregnancy

https://www.peertechzpublications.com

\begin{abstract}
Gestational gigantomastia is a rare pathology resulting in diffuse and excessive breast growth during pregnancy. Its incidence is estimated at 1 case / 100,000 pregnancies. It is thought to be linked to an exaggeration of the physiological hyperplastic phenomena of pregnancy caused by an increase in oestrogen or progesterone receptors. It is associated with the appearance of ulcerations and cutaneous necrosis of the breast, which brings into play the maternal prognosis and the pregnancy. Although benign, it can lead to a great social, emotional and physical handicap. In the rare cases reported in the literature, the treatment of gestational gigantomastia has varied on a case-by-case basis depending on the team and the presence or absence of complications. Medical treatments have been proposed mainly based on bromocriptine and reduction or radical surgical interventions (bilateral mastectomy) have been justified in cases which do not regress or which present significant complications. We report the case of a 32 year old patient who presented a gestational gigantomastia from the 14th week of amenorrhoea and who was put on bromocriptine with the result of a good neonatal outcome and a very favourable evolution in post partum with total regression of the volume of both breasts.
\end{abstract}

\section{Introduction}

Gigantomastia is a rare disease generally bilateral characterized by diffuse and excessive breast growth. Gestational Gigantomastia (GG) is a subtype of gigantomastia that occurs during pregnancy, usually in the first or early second trimester [1]. The first reported case of GG was described by Palmuth in 1648, and is believed to affect about 1 in 100,000 pregnancies [2].

The etiology of the disease is unknown, but various theories, including endocrine imbalance, hyperprolactinemia and target organ hypersensitivity, have been proposed [4]. The choice of treatment for these patients is different depending on the severity of each case [5] Only a few cases of complete spontaneous postpartum resolution have been reported in these patients and management may involve medical treatment with bromocriptine and/or surgical treatment by breast reduction or mastectomy and delayed reconstruction [3].
We report a rare case of pregnant gigantomastia that progressed favourably on bromocriptine post partum after a pregnancy marked by premature delivery at 33 weeks amenorrhea.

\section{Clinical case}

This is a 32 year old patient, 3rd gesture, 2 years old, the two previous pregnancies took place without particularities and brought to term.

patient had no medical or surgical history. The patient, who was 22 weeks amenorrhea pregnant, presented to the obstetrical clinic for bilateral mastodynia associated with a significant increase in volume of both breasts. This breast hypertrophy was progressive from the 14 th week of amenorrhea of pregnancy. The patient never reported having such an incident in other pregnancies nor any personal or family history of breast pathology. the patient also reported small respiratory genes, lack of comfort and generalized 
anxiety disorder. This pathological state was the consequence of the excessive growth of the volume of the breasts, which kept her bed-ridden, especially at the level of the spine, due to the supine position she was forced to adopt because of the size of her breasts, which prevented her from walking normally or even changing position in bed. The patient also reported a scratching sensation in both breasts.

The patient was apyretic, normo-cardenic, eupneic, The senological examination found two very enlarged breasts, very tense, the skin was very thick giving the appearance of an orange peel skin(Figure 1), with the presence of ulcerations, more marked skin erosions at the level of the external quadrants and signs of scratching around these ulcerations (Figure 2). We note the absence of palpable mammary nodule, nor mammary discharge, nor palpable axillary adenopathy. The biological blood test found: Haemoglobin: $11.2 \mathrm{~g} / \mathrm{dL}$, leukocytes 12,000 per $\mathrm{mm} 3$, platelet count 250,000 per $\mathrm{mm}^{3}$, a small biological inflammatory syndrome with a sedimentation rate (ESR) of $68 \mathrm{~mm} / \mathrm{h}$, a CRP of $20 \mathrm{mg} / \mathrm{L}$, hyperprolactinemia $110 \mathrm{ng} / \mathrm{Ml}$. The blood ionogram and the thyroid and liver tests were normal. The breast ultrasound was carried out showing a significant thickening of the skin and linear hypoechoic areas without any sign of abnormal growth, which is consistent with breast hypertrophy without any sign of malignancy. She then underwent bilateral breast biopsies to rule out carcinoma. The biopsies showed no histological signs of malignancy. The obstetrical ultrasound showed an evolving mono-fetal pregnancy with measurements corresponding to 22 weeks of amenorrhoea, without any malformations detected.

It was decided to put the patient under medical treatment based on bromocriptine $2,5 \mathrm{mg}$ twice a day associated with local care and local antibiotic based on fusidic acid ointment for the ulcerations. The evolution was marked by the reduction of breast

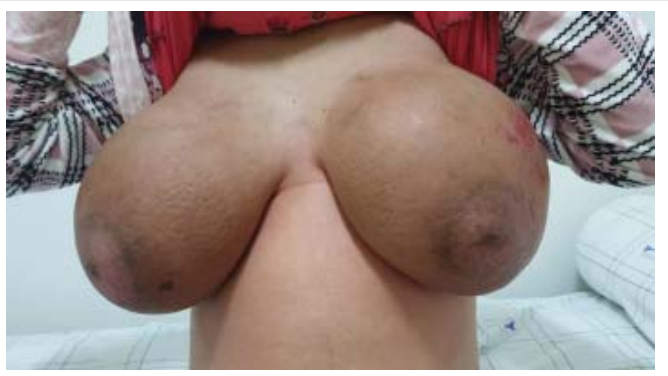

Figure 1: Image showing the significant increase in volume of the two breasts which are taut, with a very thick 'orange peel' breast skin.

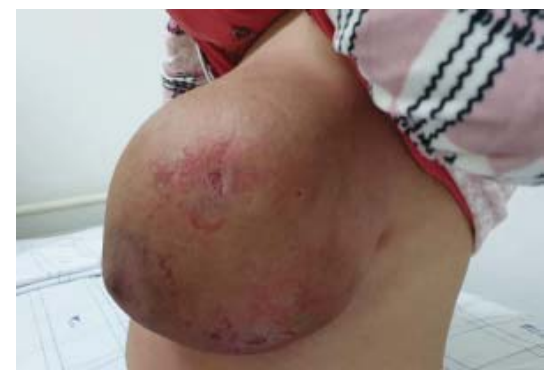

Figure 2: Image showing the presence of ulcerations and erosions on the hypertrophied breasts. tension and mastodynia and the progressive disappearance of the ulcerations, but without any improvement in breast volume. The course of the pregnancy was marked by the occurrence of a premature delivery at 33 weeks of amenorrhoea, which resulted in the birth of a male baby weighing 2680 grams, Apgar at 7 (1st min) and 9 (5th min). The post partum was without any particularities and the treatment with bromocriptine was kept. The evolution was marked by a clear clinical improvement of the breasts and a clear decrease of the breast volume from the third week of the post partum and the patient found her normal breast volume at the sixth week of the post partum.

\section{Discussion}

Gestational gigantomastia is a rare condition. Its incidence is estimated at one case per 30,000 to 100,000 pregnancies [1]. It is thought to be linked to an exaggeration of the physiological hyperplastic phenomena of pregnancy, driven by an increase in oestrogen or progesterone receptors. This is not described by all authors $[6,7]$. The age of onset is not specific. However, it is common in multiparous women after the first normal pregnancies [8]. The diagnosis is based on a range of arguments. In all cases it is marked by a very rapid increase in breast volume of more than $1500 \mathrm{cc}$ [9]. It is essentially bilateral with the presence of an inflammatory aspect with skin thickening and the occurrence of turgidity of the breast veins. Imaging is poor. Ultrasound is the most effective routine examination in pregnancy and inflammatory conditions. It shows an oedematous thickening of the skin and glandular structures $[6,9]$. It can be used to characterise or detect associated lesions [10]. The biological assessment shows a variable increase in prolactinemia not linked to a pituitary anomaly. The histology required for an inflammatory increase in the breasts shows a florid pluristratified epithelial proliferation with papillary structures, without atypia, the epithelial cells are vacuolised showing significant secretory activity. In the stroma there is oedema, sclerosis and necrosis [9,11]. The caricatural aspect in this context should not obscure the possibility of other rare mastopathies such as breast lymphomas [10]. It is a condition which is not well tolerated because of the pain which is common [12]. The treatment is not well codified. Medical, obstetric and surgical treatments have been proposed [13,14]. It depends on the team, the term, the prognosis of the pregnancy, and the breast trophic disorders. At the beginning of pregnancy some authors have proposed a therapeutic termination of the pregnancy. It comes up against the choice of the patient and the health care team and ethical problems [13]. Beyond the first trimester, monitoring is recommended until the egg matures and is ready for surgical extraction. Local care and correction of humoral deficits in the mother are provided [9]. Bromocriptine has been the mainstay of medical management of patients with gestational Gigantomastia. It is a derivative of ergot, a dopamine D2 receptor agonist, which has both agonist and antagonist properties on D1 receptors. It has been shown to be safe in pregnancy, as the incidence of abortion, ectopic pregnancy and birth defects in women taking bromocriptine, even in early pregnancy, has not been significantly different from that of non-users [15]. Although no major side effects have been reported, some isolated case reports suggest

Citation: Moussaoui KE, Ansari AC, Baidada A, Kharbach A (2021) Conservative management of gestational gigantomastia: A case report. J Gynecol Res Obstet 7(2): 027-027. DOI: https://dx.doi.org/10.17352/jgro.000100 
intrauterine growth retardation as an isolated side effect [2]. It is therefore recommended that fetal growth be monitored in patients on bromocriptine. Bromocriptine certainly has a role in stopping growth and hyperplasia of breast tissue, but it has not been proven to cause regression of gigantomastia. Many other drugs such as $2 \mathrm{Br}$-alpha ergocryptineles ,androgens, oestrogens and progesterone have also been tried, but with limited success [16] The lack of significant improvement on bromocriptine has led to the surgical options of mastectomy and breast reduction if local conditions permit. Reduction uses conventional techniques such as the inverted "T" and upper or lower pedicle. However, on very large breasts, the attempt to preserve the nipple-areolar plaque is risky [17]. Mastectomy can be combined with autologous or prosthetic breast reconstruction [18]. Hormonal treatments based on oestrogen, progesterone and testosterone have not proved effective [13]. The prognosis is essentially local. Breast hygiene and good obstetric care should be ensured [9].

In our case, we have underlined the importance that bromocriptine can play in the management of pregnant gigantomastia and that certain cases can have a good evolution in post partum under simple local care and bromocriptine treatment without resorting to surgery.

\section{Conclusion}

A good knowledge of this rare but distressing pathology is necessary for all doctors, especially obstetricians. A multidisciplinary team consisting of an obstetrician, a plastic surgeon, an anaesthetist and a paediatrician is necessary to ensure a successful delivery. Bromocriptine remains an interesting medical alternative in the management of pregnant gigantomastia.

\section{Authors'contributions}

KE made substantial contributions to conception and design, acquisition of data, analysis and interpretation of data; he has been involved in drafting the manuscript and revising it critically for important intellectual content. ACA made substantial contributions to interpretation of data and she has beeninvolved in drafting the manuscript and revising it critically for important intellectual content. $A B$ and $A K$ made substantial contributions to conception and design and acquisition of data; they has been involved in drafting the manuscript.

\section{Availability of data and materials}

The datasets used and/or analyzed during the current study are available from the corresponding author on reasonable request.

\section{Ethics approval and consent to participate}

Ethics approval has been obtained to proceed with the current study . Consent to participate not applicable.

\section{Consent for publication}

Written informed consent was obtained from the patient's parent/guardian for publication of this case report and any accompanying images. A copy ofthe written consent is available for review by the Editor-in-Chief of this journal.

\section{Competing interests}

The authors declare that they have no competing interests.

\section{References}

1. Dancey A, Khan M, Dawson J, Peart F (2008) Gigantomastia - aclassification and review of the literature. J Plast Reconstr Aesthet Surg 61: 493-502. Link: https://bit.ly/3bbpLbV

2. Rezai S, Nakagawa JT, Tedesco J, Chadee A, Gottimukkala S, et al. (2015) Gestational gigantomastia complicating pregnancy: A case report and review of the literature. Case Rep Obstet Gynecol 2015: 892369. Link: https://bit. $\mathrm{ly} / 3 \mathrm{xYHj} 51$

3. Ezem BU, Osuagwu CC, Opara KA (2011) Gestational gigantomastia with complete resolution in a Nigeri-an woman. BMJ Case Rep 2011: bcr0120102632. Link: https://bit.ly/3nZk0U8

4. Zargar AH, Laway BA, Masoodi SR, Shah NA, Darzi MA, et al. (1995) Gestationa macromastia not responding to termination of pregnancy. Postgrad Med $\mathrm{J} 71$ : 124-125. Link: https://bit.ly/3vUddhf

5. Williams PC (1957) Massive hypertrophy of the breasts and axillary breasts in successive pregnancies. Am J Obstet Gynecol 74: 1326-1329. Link: Link: https://bit.ly/3uBOfVg

6. Boufettal H, Khalkane L, Dlia H, Mahdaoui S, Hermas S, et al. (2009) Gigantomastie gravidique bilatérale: à propos d?un cas. Jour Gyn Obs Biol Reprod 38: 254-257.

7. Houssine B, Leila K, Mahdaoui S, Hermas S (2001) La gigantomastie gravidique bilatérale: à propos d'un cas. Imagerie de la femme 23: 32-35.

8. Chavoin JP, Canizares F, Mojallal A, Fabre G, Grolleau JL (2005) Hypotrophie et ptôse mammaire. Ann Chir Plast Esth 50: 476-486. Link: https://bit.ly/3tyLQYu

9. Dem A, Wone H, Faye ME, Dangou JM, Toure P (2009) la gigantomastie gravidique: à propos d'un cas. J Gyn Obst Biol Reprod 38: 254-257. Link: https://bit.ly/3vUXgaq

10. Schmid N, De Greef C, Calteux N, Duhem C, Faverly D (2008) Réduction mammaire selon la technique verticale pour gigantomastie avec fibroadénomatose massive: à propos d'un cas clinique. Ann Chir Plast Esth 53: 342-347.

11. Vandenberghe G, Claerhout F, Amant F (2005) Lymphoblastic lymphoma presenting as bilateral gigantomastia in pregnancy. Int $\mathrm{J}$ Gynaecol Obstet 91 : 252-253. Link: https://bit.ly/3xY3d8y

12. Lapid O, de Groof EJ, Corion LU, Smeulders MJ, van der Horst CM (2013) The effect of breast hypertrophy on patient posture. Arch Plast Surg 40: 559-562. Link: https://bit.ly/3evET63

13. Eben F, Cameron MD, Lowy C (1993) Successful treatment of mammary hyperplasia in pregnancy with bromocryptine. Br J Obstet Gynaecol 100: 9596. Link: https://bit.ly/33uqVLv

14. Greely PW, Robertson LE, Curtin JW (1965) Mastoplasty for bilateral benign breast hypertrophy associated with pregnancy. Ann Surg 162: 1081-1083. Link: https://bit.ly/3xYHFsn

15. Krupp P, Monka C (1987) Bromocriptine in pregnancy: Safety aspects. Klin Wochenschr 65: 823-827. Link: https://bit.ly/3f0qQVi

16. Kullander S (1976) Effect of 2 br-alpha-ergocryptin (CB 154) on serum prolactin and the clinical picture in a case of progressive gigantomastia in pregnancy. Ann Chir Gynaecol 65: 227-233. Link: https://bit.ly/3beGHP2 
17. Segall JJ (2005) Plastie mammaire de réduction et mastopexie avec cicatrices verticale et horizontale limitées « mini T inversé »: expérience de 184 cas. EMC Chir 2: 500-516
18. Boyce SW, Hoffman PG, Mathes SJ (1984) Recurrent macromastia after subcutaneous mastectomy. Ann Plast Surg 13: 511-518. Link: https://bit.ly/3bgt15X
Discover a bigger Impact and Visibility of your article publication with

\section{Peertechz Publications}

\section{Highlights}

* Signatory publisher of ORCID

* Signatory Publisher of DORA (San Francisco Declaration on Research Assessment)

* Articles archived in worlds' renowned service providers such as Portico, CNKI, AGRIS, TDNet, Base (Bielefeld University Library), CrossRef, Scilit, J-Gate etc.

* Journals indexed in ICMJE, SHERPA/ROMEO, Google Scholar etc.

* OAI-PMH (Open Archives Initiative Protocol for Metadata Harvesting)

* Dedicated Editorial Board for every journal

* Accurate and rapid peer-review process

* Increased citations of published articles through promotions

* Reduced timeline for article publication

Submit your articles and experience a new surge in publication services (https://www.peertechz.com/submission).

Peertechz journals wishes everlasting success in your every endeavours.

Copyright: @ 2021 Moussaoui KE, et al. This is an open-access article distributed under the terms of the Creative Commons Attribution License, which permits unrestricted use, distribution, and reproduction in any medium, provided the original author and source are credited.

Citation: Moussaoui KE, Ansari AC, Baidada A, Kharbach A (2021) Conservative management of gestational gigantomastia: A case report. J Gynecol Res Obstet 7(2): 027-027. DOI: https://dx.doi.org/10.17352/jgro.000100 